\title{
Deliberative citizenship and social management: a systematic literature review in Brazil
}

\author{
RAFAel JUNiOR dos SANTOS FigueIREdo SALGado ${ }^{1}$ \\ LUANA FERREIRA dOS SANTOS ${ }^{1}$ \\ TAMIRIS CRISTHINA RESENDE ${ }^{1}$ \\ WASHINGTON JOSÉ DE SOUZA ${ }^{1}$ \\ ${ }^{1}$ Universidade federal do Rio Grande do norte / Graduate Program in Administration, Natal - RN, Brazil
}

\begin{abstract}
This systematic literature review about deliberative citizenship aims to synthesize, in social management studies in Brazil, the application of the concept as portrayed by Habermas. The Periódicos Capes and Academic Google databases were searched using the descriptors "deliberative citizenship" and "social management." Most of the articles were published in journals classified in the stratum Qualis Capes A2, and in Cadernos EBAPE.BR. The analysis of the methodological strategies employed reveals qualitative options, with seven papers characterized as theoretical essays and eleven papers as theoretical-empirical, by the application of the concept of deliberative citizenship in territories and councils. The theoretical-empirical results focus on challenges and opportunities and indicate that the process of Habermasian deliberative citizenship can constitute a social management strategy. The theoretical texts indicate that the construct deliberative citizenship provides elements related to the construction of the domain of social management.
\end{abstract}

Keywords: Deliberative citizenship. Jürgen Habermas. Social management. Social participation.

\section{Cidadania deliberativa e gestão social: revisão sistemática de literatura no Brasil}

\section{Resumo}

Esta revisão sistemática de literatura de cidadania deliberativa e gestão Social tem por objetivo analisar o modo como o conceito habermasiano de cidadania deliberativa é aplicado em estudos de gestão social no Brasil. Para tanto, foram consultadas as bases de dados Periódicos Capes e Google Acadêmico, usando os descritores "cidadania deliberativa" e "gestão social". A maioria dos artigos foi publicada em revistas classificadas no estrato Qualis Capes A2, tendo como principal periódico o Cadernos EBAPE.BR. A análise das estratégias metodológicas empregadas revela opções qualitativas, com 7 trabalhos caracterizados como ensaios teóricos e 11 estudos teóricos-empíricos, predominando a aplicação da concepção de cidadania deliberativa em territórios rurais e conselhos. Os resultados teórico-empíricos enfocam desafios e oportunidades de pesquisa e (re)afirmam que o processo de cidadania deliberativa habermasiano pode ser tomado como estratégia de gestão social. De outra forma, os textos teóricos indicam que o constructo cidadania deliberativa constitui base relevante para a construção do domínio da gestão social.

Palavras-chave: Cidadania deliberativa. Jürgen Habermas. Gestão social. Participação social.

\section{Ciudadanía deliberativa y gestión social: una revisión sistemática de la literatura en Brasil}

\section{Resumen}

Esta revisión sistemática de la literatura sobre ciudadanía deliberativa y gestión social tiene como objetivo analizar la aplicación del concepto habermasiano de ciudadanía deliberativa en estudios de gestión social en Brasil. Para ello, se consultaron las bases de datos Periódicos Capes y Google Académico con los descriptores "ciudadanía deliberativa” y "gestión social”. La mayoría de los artículos fue publicada en periódicos de categoría Qualis Capes A2, entre los cuales el principal es Cadernos EBAPE.BR. El análisis de las estrategias metodológicas empleadas revela opciones cualitativas, con 7 trabajos caracterizados como ensayo teórico y 11 trabajos teórico-empíricos, en los cuales predomina la aplicación de la concepción de ciudadanía deliberativa en territorios rurales y concejos. Los resultados teórico-empíricos enfocan desafíos y oportunidades de investigación y reafirman que el proceso de ciudadanía deliberativa habermasiana puede emplearse como estrategia de gestión social. Por otro lado, los textos teóricos indican que el constructo ciudadanía deliberativa es una base relevante para la construcción del dominio de la gestión social.

Palabras clave: Ciudadanía deliberativa. Habermas. Gestión social. Participación social.

Article submitted on August 23, 2018, and accepted for publication on January 15, 2019

[Translated version] Note: All quotes in English translated by this article's translator.

This study was undertaken with support from the Coordination for the Improvement of Higher Educational personnel (Capes) - Financing Code: 001

DOI: http://dx.doi.org/10.1590/1679-395176139x 


\section{INTRODUCTION}

This systematic review of the literature analyzes how the social management studies in Brazil apply the concept of deliberative citizenship proposed by Jürgen Habermas. This concept is linked to the notion of communicative purpose, with the author introducing a paradigm shift, replacing Max Horkheimer and Theodor Adorno's philosophy of consciousness, for the theory of communicative intersubjectivity (FREITAG, 1994). E. Freitag (1994) defends that the relevance of the joint action of the Frankfurt School theorists lies with intellectual and critical capacity, dialectic reflection and dialogical competency. The author highlights that the essential basis of the theory is emancipation, connected to the replacement of instrumental rationality by the emancipatory purpose of man, configured by the concept of communicative rationality, for radical, collective and democratic reflection, and policy renegotiation, understood as a field in which everyone should participate.

Despite Habermas' agreement with Hockheimer and Adorno's criticism of instrumental purpose, hindering the social autonomy of individuals, he devises a way out for man, without compromising technical-scientific progress (TENÓRIO, 1998). Therefore, he formulates a theoretical-social paradigm to address this type of instrumental purpose, where a communicative model of social action should achieve a consensus. Thus, Habermas' (2011a) communicative rationality refers to relations in which stakeholders are involved with the world, where they claim validity for their demonstrations or outputs through communicative action. This rationality focuses on decentralizing an understanding of the world, which is one of the conditions required for an emancipated society.

In Brazil, it was Tenório (1998) who originally incorporated Habermas' discussion of deliberative citizenship into social management. The integrated analysis of the two constructs is centered on participation, since "social management should be practiced as an intersubjective, dialogical process, in which everyone has the right to speak" (TENÓRIO, 2005, p. 121). According to Tenório (1998), self-determination does not take place under market logic, but from social democracy, by way of equality in politics and decision-making. This is the background that justifies the systematic review presented here. At later dates, various Brazilian authors incorporated the concept of deliberative citizenship into social management and, therefore, this review is focused on unveiling how these uses occurred from the following question:

- Within the field of social management, how are Habermas' precepts of deliberative citizenship presented and what is the profile of academic production by authors in Brazil?

The review starts from the premise that the exercise of deliberative citizenship requires participation, but is contrary to the notion of the citizen in a liberal perspective, considering that the foundation of this resides in subjective rights that improve with the State and other citizens, within limits established by laws, for their benefit (HABERMAS, 1995).

The public sphere guides the work that analyzes the theoretical-conceptual approaches of the social management theories of Jürgen Habermas (OLIVEIRA, CANÇADO and PEREIRA, 2010; GARCIA, 2016; PERSSON, 2016) or they appropriate Habermas' concepts to analyze the actions and experiences grounded in social management (ALLEBRANDT, SIEDENBERG, SAUSEN et al., 2011; IIZUKA, GONÇALVES-DIAS and AGUERRE, 2011, 2012; ALLEBRANDT, BENSO and OLIVEIRA, 2015). Thus, the discussion outlined here innovates not only on accomplishing the theoretical-empirical exercise of the approach between social management and Habermas' notion of deliberative citizenship but also on revealing how the two constructs are approached, together, in Brazilian intellectual production on the topic.

The systematization performed here brings to the surface readings of life in society in Brazil, in the light of deliberative citizenship, in a broad sense, from the use of this expression, within the area of social management studies, the privileged locus of the intersubjectivity of supportive management (TENÓRIO, 1998), and dialogical relations between citizens who experience decision-making processes at organizations. Therefore, it represents a contribution to studies on citizenship in Brazil, by demonstrating the applications, possibilities, advances and dilemmas of deliberative citizenship practices at non-state public organizations. In other words, a cross-section of the stage in which the Brazilian debate on social management experiences and of dialogical processes established on the notion of deliberative citizenship are situated is addressed here.

Following this introduction, the article highlights Jürgen Habermas' main concepts and discussions on deliberative citizenship in social management. The text continues by demonstrating the methodological procedures used in the literature review, originating from searches on the Capes Journal and Google Scholar databases. The subsequent analysis of the results 
summarizes the profile of the 18 texts collected and how Habermas' precepts are incorporated into social management studies, highlighting the deliberative citizenship construct. As a conclusion, the authors' selection of qualitative approaches is clear, with seven texts published as theoretical essays and 11 as theoretical-empirical exercises in collegiate management spaces, predominantly in territories and public policy councils.

\section{APPROXIMATIONS BETWEEN SOCIAL MANAGEMENT AND DELIBERATIVE CITIZENSHIP}

Habermas' concept of communicative action, the base of the construction of the term social management, as conceived by Tenório (1998), centers on a social act, which refers to an interaction between a minimum of two subjects, capable of language and action, engaged in an interpersonal relation (HABERMAS, 2011a). For Habermas (2011b), communicative action assumes that the strength of social integration encompasses a wide range of autonomous public spaces and procedures for the democratic formation of political opinions and desires. It is from the notion of communicative action, which derives from Habermas' concept of life-world. Communicative action takes place in the life-world, made up of the structural components culture, society and personality.

Communicative action and the life-world are directly related since the former produces the symbolic structures of the latter. Under the aspect of mutual understanding, communicative action serves to transmit and renew cultural knowledge; under the aspect of action, it fosters social integration and the creation of solidarity and under the aspect of socialization, it contributes towards the formation of an individual personality. In life-world, symbolic reproduction takes place through social integration.

For Habermas, there are three normative models of democracy that can be related to ideal types of citizen, as Tenório (1998) suggests: a) a liberal citizen, who has rights emanating from the State, in favor of private interests established by law; b) a republican citizen who, in addition to using their freedom for private interests, uses participation as standard practice, in order to become a political actor in a society, and c) a citizen who practices the deliberation model that, once guided by communicative rationality, is eager for understanding and consensus, through argumentation, based on the structure of linguistic communication. The deliberation model "is based precisely on communication conditions, in which the political process may have the presumption of generating rational results in its favor, because in this, the form and style of deliberative policy are fully accomplished" (HABERMAS, 1995, p. 45, our translation). Thus, the concept of deliberative citizenship was conceived and incorporated initially into Brazilian literature by Tenório (1998), in his article "Gestão social: uma perspectiva conceitual".

Tenório's (1998) pioneering text guided social management, both within the scope of governments, especially in the implementation of public policies, and private organizations in business management. Therefore, social management was conceived as a dialogical, management process in which the participants of a particular action share the power of decision, in any social system - public, private or third sector organizations (TENÓRIO, 1998). Later, Tenório (2005) noted that Habermas' model of democracy of deliberative citizenship is based on the correlation between human rights and popular sovereignty and a reinterpretation of autonomy, within the molds of discourse theory. This understanding incorporates the intersubjectivity of processes of understanding (HABERMAS, 1995) that take place in the institutionalized form of deliberations in parliamentary institutions or communication networks of political public spaces. In this direction, Tenório (1998, p. 18-19) defends that the model of deliberative citizenship represents:

[...] real social management [...] in which an individual should take part in a democratic procedure, deciding, in the different arenas of a society and different roles, their social destiny as a person [...], in other words, their self-determination does not take place under market logic, but from social democracy: equality in politics and decision-making.

For Tenório (1998, p. 19), it is in the third sector that this environment is useful, since "the privileged [locus] of social integration and intersubjectivity sought by more caring management" resides within the scope of civil society organizations.

Therefore, citizenship requires an appropriate political identity to unite different groups and favor a specific collective identity for the group of individuals belonging to a particular community, which reinforces the presence of principles and loci of the field of social management and management of civil society organizations, from the so-called third sector. Tenório (2005, p. 102) confirms that the "social" adjective qualifying the noun "management", could be "understood as a privileged space 
of social relations, where everyone has the right to speak, without any type of coercion." Therefore, social management, when related to topics that involve public, bureaucratic apparatus, becomes a decision-making process that takes place in the public sphere, a place where society and the State interact, to promote extended public administration (TENÓRIO, 2010).

The public sphere is presented as a space for intermediation between the State, society and the market - and, deliberative citizenship, a participative process of deliberation based, primarily, on understanding (and not in convincing or negotiating) between the parties. The procedure of the practice of deliberative citizenship in the public sphere is participation (TENÓRIO, 2008a), which requires Habermas' communicative action. For this reason, Tenório (2008a) defends that social management should be orientated by communicative rationality, in a context in which the actors, on making proposals, cannot impose claims of validity without an agreement being reached communicatively, with all the participants presenting arguments for debate or on a specific project under construction.

It is relevant to consider that, under conditions that are appropriate for the exercise of deliberative citizenship, a citizen does not exclusively use freedom in their interest and the defense of private interests, but also as an exercise, which enables them to become what they intend to be: a political person responsible for a community of free and equal people (HABERMAS, 1995). Social management follows similar principles, since "while strategic management seeks to objectify the 'adversary' through the private sphere, social management should serve the common good of society, through the public sphere." (TENÓRIO, 2006, p. 1147-1148). Thus, notions are placed of communities of free and equal people who promote the common good of society in the public sphere. Therefore, this is the intersection this text recognizes and that justifies the theoretical exercise undertaken here, which is, of qualifying how they present Habermas' precepts of deliberative citizenship, within the domain of social management.

Other Brazilian authors address social management following similar bases - the collegiate locus of deliberation, a process that aims to achieve the emancipatory purposes and interests of society, practices of shared knowledge and collective decisionmaking, based on the ineligibility of language. In França Filho $(2003,2008)$, social management takes two approaches: as a process (organizational level) and a purpose (macro level - the problem of society). In turn, Fischer (2002), uses the term social development management, taken as a reflexive space of practices and knowledge, made up of several subjects. Carrion (2007) has another objective: the "location", considered a privileged locus for social management, not only within the geographical scope but, fundamentally, in the cultural and identity particularities of every community, since social management focuses on changing the morphology of social, in a perspective of local, integrated development.

Cançado (2011) takes social management as a process from collective decision-making, without coercion, based on the intelligibility of language, dialogicity and understanding, clarified as a process, with transparency as the assumption and emancipation as the objective. The author understands that social management sets off from a well-understood interest (IBC), takes place in the public sphere and has the goal of emancipation. Souza and Oliveira (2006, p. 60) also follow the bias of decision-making and emancipation, defining social management as:

[...] a set of organizational strategies and policies to promote the well-being of individuals and collectives, aimed to restore the links integrating man with fellow man and the environment, joining elements of substantive rationality to instrumental rational action, under the ideal of human emancipation.

The option defended by Jürgen Habermas of a notion of decision-making, based on elements of substantive rationality, is evident among the authors, although interceded by instrumental rationality, as Souza and Oliveira (2006) suggest.

As the objective, in other words, as the problem of society (FRANÇA FILHO, 2003, 2008), social management tends to take the aims of emancipation through participative exercises. Therefore, social management is the objective (seeking emancipation) and process - intersubjective and dialogical, which takes place in a social space, in the public sphere, joining different actors from civil society, sometimes interacting with the State, at others interacting with the market and, at times, the three together. Likewise, Tenório (2008a, 2008b), taking Habermas' constructs of deliberative citizenship and communicative action as a basis, attributes a democratic nature to social management, with the decision making place through understanding and not negotiation, to promote the common good. Since the central component of the approximation between social management and deliberative citizenship resides in this point, the path adopted, to a greater or lesser extent, by Brazilian authors, as noted both in this summary and the analysis of the information of this research, presented below. 
Social management has been the subject of study and practices associated with the arrangements of civil society, the monitoring and evaluation of social policies, at collegiates that focus on combating poverty and the topics of sustainability and the environment and these are the biases that emerge in this review, notably at territorial collegiates and of public policy control. Discussion of democratic and participative management, whether in formulating public policies or in relations of a productive nature (TENÓRIO, 2008c), do not appear in the approaches considered here. Therefore, this review follows a tendency that is not able to account for the theoretical and analytical potential of the term (CANÇADO, TENÓRIO and PEREIRA, 2011), since addressing social management is thinking beyond public policy management, and the social field enables connections to be established between intervention and transformation actions, through a diverse range of actors.

\section{METHODOLOGICAL PROCEDURES}

The Prisma protocol orientated how this systematic review was undertaken. It is presented in 27 items and a four-stage flowchart and aims to contribute, so that authors improve reports of systematic reviews and meta-analyses (GALVÃO, PANSANI and HARRAD, 2015). The systematization started with a search for texts using the keywords "deliberative citizenship" and "social management", together, without a time criterion. Two procedures were applied, to locate the intellectual production sought: a) preliminary search on the Capes Journals database for texts written in Portuguese exclusively in the area of concentration/ evaluation of Public Administration, Administration, Accounting and Tourism, and b) a confirmatory search on Google Scholar. The search was carried out in June 2017.

The first search, on the Capes Journal database, produced 17 records and the second, on Google Scholar, produced four. Selection and exclusion criteria were then applied to the two collections, which considered: a) the exclusion of duplicates; b) alignment of the content of the material selected with the problem of this review, and c) compatibility of the material collected during the searches. Based on these criteria, three records from the preliminary result were excluded from the search on the Capes Journal database - two due to duplication and one as the content did not align with the purpose of this review - this was the case of the text by Silva, Lima, Gomide et al. (2017).

Having completed the search and selection, inclusion/exclusion procedures, the next step was carried out with the assistance of Computer Assisted Qualitative Data Analysis (CAQDAS), and Zotero 5.0 reference management software was used to order the collected texts. The sequence included summarizing the material collected on a spreadsheet using Microsoft Excel software, with the following information: title; Qualis; volume; number and year of publication; author and institution; abstract and keywords in the text; number of references and quotations; problem and objective; most quoted authors; theoretical basis and application context; identification of audience coverage subject selection criterion; type of research and epistemological framework; methodological framework; collection procedure and analysis and main conclusions.

The data were processed on CAQDAS VOSViewer, in order to define the author network and on the Nube de Palabras (2017) site to identify the words most quoted in the titles. Formatted in two stages (screening and analysis processes), Figure 1 summarizes the trajectory of the review undertaken, alongside the respective result attained in each phase ( 4 from screening and 5 from analysis). 
Figure 1

Summary of the systematic review process

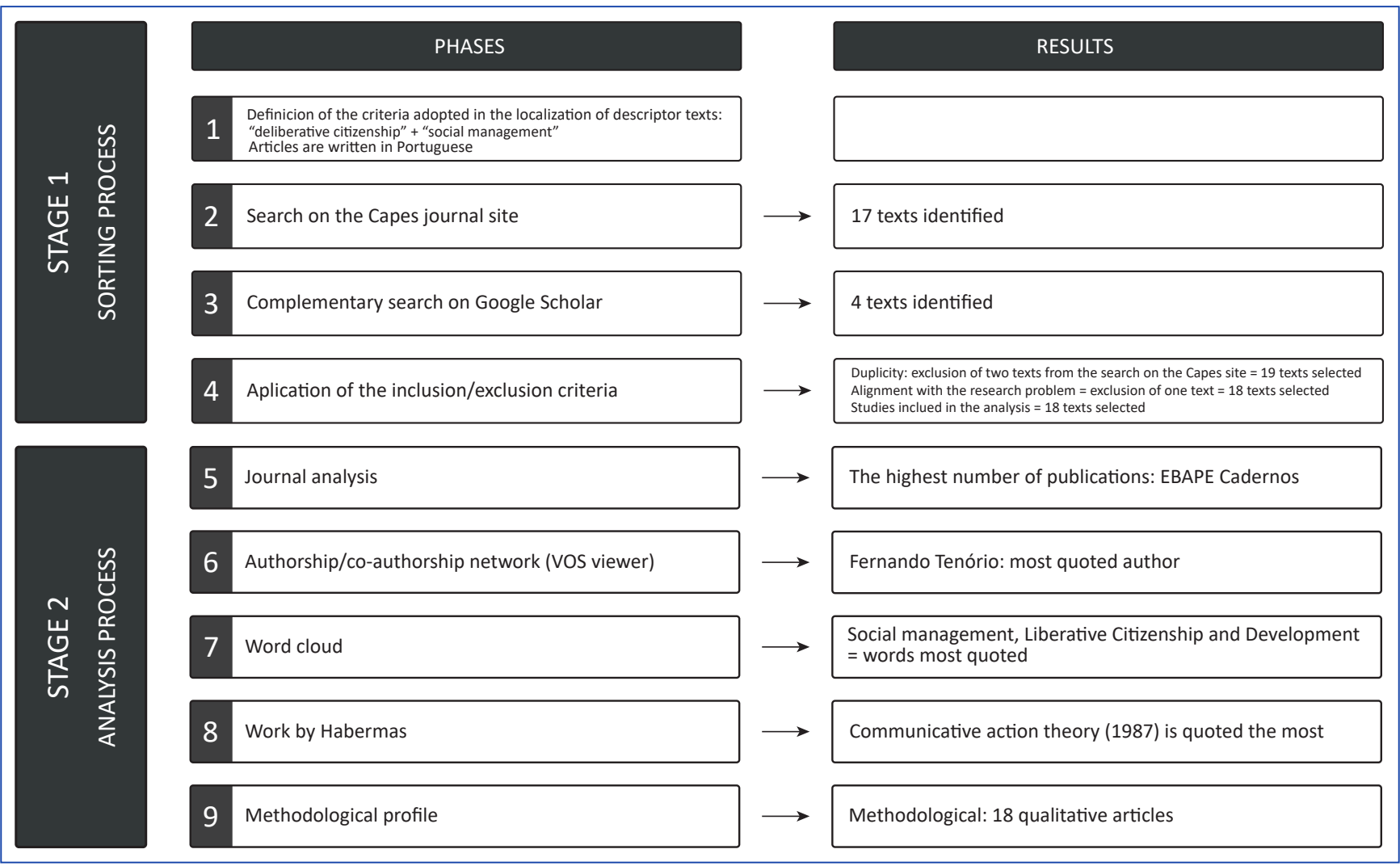

Source: Elaborated by the authors.

\section{ANALYSIS OF THE RESULTS}

Box 1 indicates that Cadernos EBAPE.BR is the journal that has the highest number of publications, accounting for 6 articles, and there were publications in other resources, which are also national. Of the 18 records, 9 are published in journals with a Qualis A2 classification, whereas the other half are in journals with Qualis B1 to B4 classifications. The first publication with the keywords social management and deliberative citizenship dates from 1998, with Fernando Guilherme Tenório as the author. The second publication only emerges in 2005, 7 years later. Another publication emerged each year, in 2009 and 2010. 2011 registers a significant advance, with 6 publications. After this year, there was a decline in publications with the above-mentioned keywords.

In 2011, Cadernos EBAPE.BR released a special edition with 11 articles on social management and this explains the significant increase in the keywords researched, specifically in this year. Among the 11 special edition articles, 5 used the keywords deliberative citizenship and social management. This result is in keeping with construction of the domain of social management, which has Jürgen Habermas' model of deliberation, the public sphere and communicative action as its constructs. The most recent publications (three) date from 2015. 


\section{Box 1}

Production summary by journal, Qualis and year

\begin{tabular}{|c|c|c|c|}
\hline Code & Journal Title & Qualis & Year \\
\hline 1 & Revista de Administração Pública & $\mathrm{A} 2$ & 1998 \\
\hline 2 & Desenvolvimento em Questão & B2 & 2005 \\
\hline 3 & Revista de Administração Pública & $\mathrm{A} 2$ & 2009 \\
\hline 4 & Cadernos EBAPE.BR & A2 & 2010 \\
\hline 5 & Cadernos EBAPE.BR & $\mathrm{A} 2$ & 2011 \\
\hline 6 & Cadernos EBAPE.BR & $\mathrm{A} 2$ & 2011 \\
\hline 7 & Desenvolvimento Regional em Debate & B4 & 2011 \\
\hline 8 & Cadernos EBAPE.BR & $A 2$ & 2011 \\
\hline 9 & Cadernos EBAPE.BR & $\mathrm{A} 2$ & 2011 \\
\hline 10 & Cadernos EBAPE.BR & $\mathrm{A} 2$ & 2011 \\
\hline 11 & Revista de Administração Pública & $\mathrm{A} 2$ & 2012 \\
\hline 12 & Revista Pensamento \& Realidade & B3 & 2012 \\
\hline 13 & Desenvolvimento Regional em Debate & B4 & 2013 \\
\hline 14 & Revista de Administração Mackenzie & B1 & 2013 \\
\hline 15 & Revista Brasileira de Gestão e Desenvolvimento Regional & B1 & 2013 \\
\hline 16 & Revista de Ciências da Administração & B1 & 2015 \\
\hline 17 & PRACS: Revista Eletrônica de Humanidades do Curso de Ciências da Unifap & B3 & 2015 \\
\hline 18 & Revisão de Gestão USP & B1 & 2015 \\
\hline
\end{tabular}

Source: Elaborated by the authors.

The majority of the authors are linked to public universities, with two from private institutions - Fernando Guilherme Tenório from the Getulio Vargas Foundation (FGV), and Sérgio Luís Allebrandt from the Regional University of the Northwest of the State of Rio Grande do Sul (Unijuí). There are 42 authors and co-authors from 19 institutions. Although present in all regions, the topic does not cover all the federated units, appearing in only eight (São Paulo, Rio de Janeiro, Minas Gerais, Bahia, the Federal District, Tocantins, Rio Grande do Sul and Santa Catarina). Although it covers practically all of the southeast region, we highlight that the majority of the authors are linked to higher education institutions (IES) in the Rio Grande do Sul. The authorship and co-authorship network, generated with support from VOSViewer software, contributes towards explaining the relation between them. The articles produced 12 clusters, highlighting the authors Fernando Guilherme Tenório (FGV) and José Roberto Pereira (Federal University of Lavras - UFLA), in a network that occurred by derivation, and Sérgio Luís Allebrandt (Unijuí). 
Figure 2

Article authorship clusters

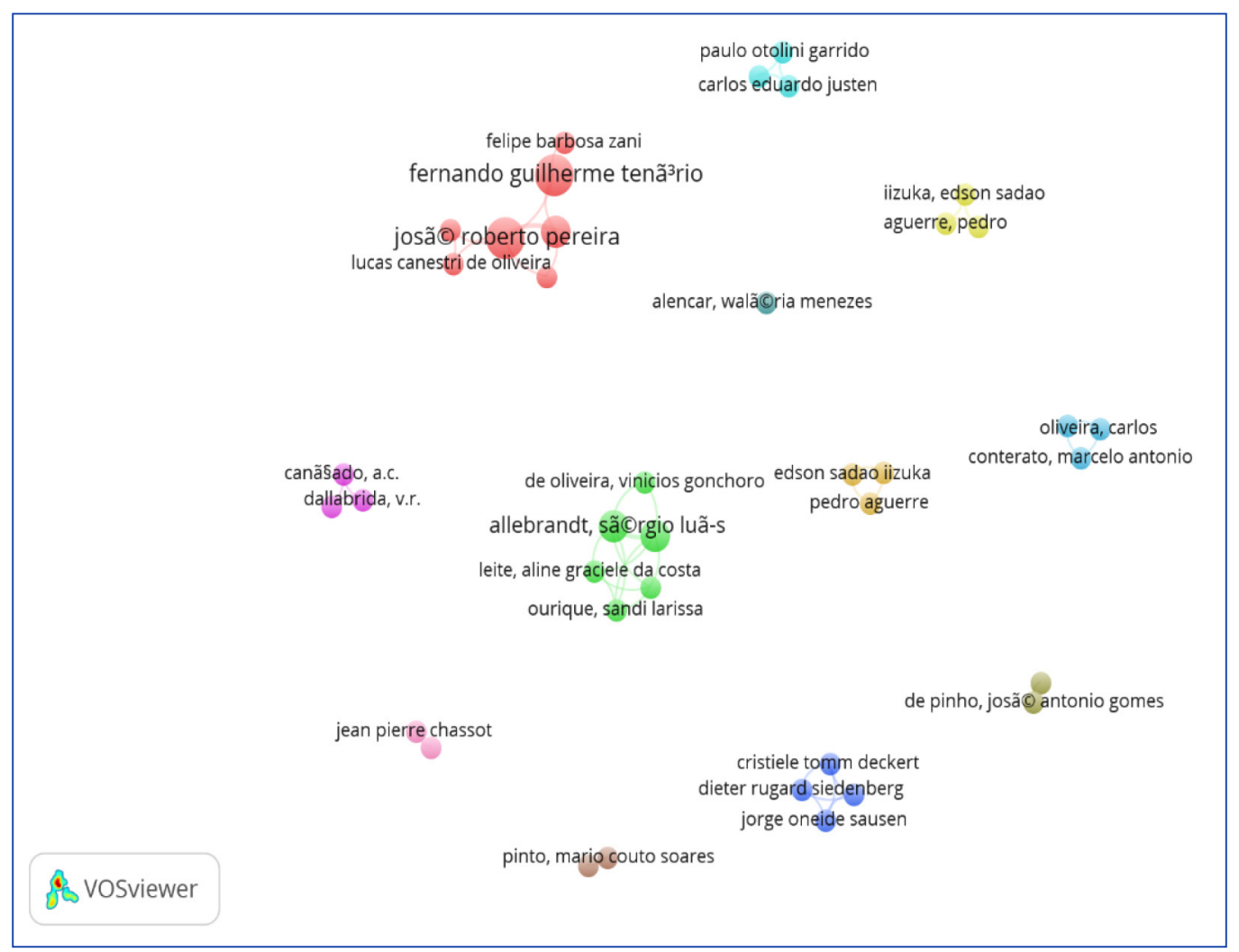

Source: Elaborated by the authors.

The site Nube de Palabras (2017) processed the titles of articles, to identify the words that appeared most frequently. The words "management" and "social" appeared 18 times each, guaranteeing that the papers approached social management as their central construct. The same phenomenon does not occur with "deliberative citizenship", since the use of similar expressions taken from Habermas' literature occurs, such as participation, deliberative democracy and communicative action. Thus, the word "citizenship" appears six times and "deliberative" three. The word "development" also appears six times. The words "participation," "territorial", "territories", "reflections", "analysis", "study" and "case" appear in two titles. 
Figure 3

Word cloud with article titles

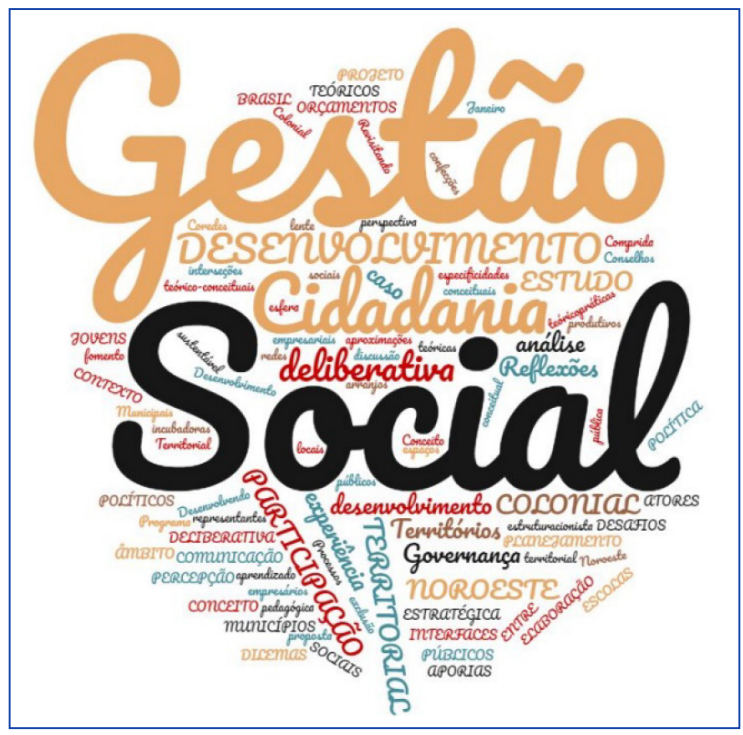

Source: Elaborated by the authors.

The aims of the articles indicate a concentration on qualitative analyses, with seven papers characterized as theoretical essays and the other 11 as empirical, mainly developed in territories and regional councils. All the articles analyzed quoted Fernando Tenório. Among the articles considered, "Gestão social: uma perspectiva conceitual," by this author, is quoted in 276 publications and "(Re)visitando o conceito de gestão social in 192. The majority of the texts analyzed address Tenório's (2005) concept of social management in their entries, in order to establish a contrast to the idea of strategic management (IIZUKA, GONCALVES-DIAS and AGUERRE, 2012), to guide specific orientation for communicative rationality (OLIVEIRA, PERAFÁN and CONTERATO, 2013) and to take substantive rationality in a similar sense to the approach adopted by Guerreiro Ramos (1981), as in the case of Allebrandt, Benso and Oliveira (2015). Other authors - Airton Cançado, Genauto França Filho, Tânia Fischer and Valdir Dallabrida - are quoted as mentioning the concept of social management.

The field of knowledge of social management appears in the articles analyzed, based on three broad, linked categories: public interest, the public sphere and social emancipation (PERES JÚNIOR, PEREIRA and OLIVEIRA, 2013). Genauto França Filho approaches the concepts of public, strategic and social management, as a way of understanding them, and to search for the meaning of the latter, which the author understands, as mentioned previously, from two perspectives: as a process related to the organizational level - and as a purpose - associated with the macro level and the problem of society (CANÇADO, TAVARES and DALLABRIDA, 2013). Another research strand that stands out in the field of social management is Tânia Fischer's interdisciplinary organizational approach, which argues that, by connecting organizations in inter-organizations that construct a particular social reality and promote development in an integrated way, social management then addresses the management of social development, characterized by partnerships, networks, consortiums, clusters, socio-productive arrangements, and similar variations (PERES JÚNIOR, PEREIRA and OLIVEIRA, 2013).

Valdir Dallabrida's studies link social management to a focus on territorial development (CANÇADO, TENÓRIO and PEREIRA, 2011), drawing on Tânia Fischer and highlighting a governance network, such as coordination and cooperative actions between social, economic and institutional actors, which express the capacities of a territory to manage public affairs (ALLEBRANDT, BENSO and OLIVEIRA, 2015). In the majority of the texts analyzed, the authors make use of Habermas' concepts. Therefore, Box 2 demonstrates Habermas' most quoted work and the papers that are supported by the author's thoughts. The Theory of Communicative Action is the most referenced work of Habermas and the associated concepts are deliberative citizenship, communicative action and communicative rationality. This demonstrates that the way the authors use the concept of deliberative citizenship in social management is in line with the way the idea is used in Habermas' work, as presented in the introduction and theoretical frame of reference of this study. 


\section{Box 2}

Classification of Habermas' quoted work by article considered in the analysis

\begin{tabular}{|l|c|}
\hline \multicolumn{1}{|c|}{ Habermas' quoted work } & Articles (code)* \\
\hline The Theory of communicative action (2011a; 2011b) & $11,16,3,1$ \\
\hline Three normative models of democracy (1995) & 14,1 \\
\hline Between facts and norms (1996) & 18,02 \\
\hline $\begin{array}{l}\text { The structural transformation of the public sphere: an inquiry into a } \\
\text { category of bourgeois society (2003) }\end{array}$ & 4,15 \\
\hline Theory and practice (1988) & 1 \\
\hline La necesidad de revisión de la izquierda (1991) & 1 \\
\hline
\end{tabular}

Source: Elaborated by the authors.

* As per the order of the texts in Box 1.

lizuka, Gonçalves-Dias and Aguerre (2012) used the foundations of deliberative citizenship as a basis for a study on Território da Cidadania Litoral Sul da Bahia (The territory of citizenship on the south coast of Bahia), as a way of understanding facts, dialogues and unexpected, non-linear events that are, for the most part, ignored by a considerable percentage of traditional administrative literature, but that, on the other hand, may be analyzed in the light of this construct. The notion of communicative action was used by Allebrandt, Benso and Oliveira (2015) to understand to what extent the communication of the Programa Territórios da Cidadania (Citizenship Territories Program) provides a space for dialogue between the organizations that seek social, political, economic, cultural and ecological achievements through this public initiative. Villela and Pinto (2009) make a connection between the concepts of communicative governance and rationality to address the democratic links in social relations that should be dialogical and not monological, when they aim to meet the needs found in business networks (and not in networks in the field of social management).

Two articles cite the Três modelos normativos de democracia (Three normative models of democracy) (HABERMAS, 1995) and also refer to the concept of deliberative citizenship and the public sphere. Among these is Tenório (1998) who highlights the model of deliberative citizenship as a proposal that Habermas defends in opposition to the liberal and republican models since this notion of citizenship is based on communicative rationality. In turn, Peres Júnior, Pereira and Oliveira (2013) use the concept of the public sphere, making a comparison with the theoretical framework of structuration theory. The authors argue that the duality of the structure makes it simultaneously the means and result of the action. Also, they provide subsidies to understanding the practices of the deliberative system and formation of the public sphere, recognizing that human action can take on an intentional, reflective and cognoscitive nature.

Tenório (2005) and Pinho and Santos (2015) cite the Habermas' work Direito e democracia: entre facticidade e validade (Between facts and norms). Tenório (2005) emphasizes that, unlike a centralizing process in which technical knowledge is the main argument of the decision, from a decentralizing perspective, the public sphere should identify, understand, question and suggest solutions to the dilemmas of society, to the point of them being taken on as public policies by a parliamentary context and executed by the administrative apparatus of government. Pinho and Santos (2015) criticize analogies from Tenório, highlighting that dilemmas of a theoretical and political nature lead to the observation that consistent theoretical justifications do not exist to substantiate the association between social management, emancipation and the public sphere, (particularly in Habermas' theoretical adaptations of deliberative democracy carried out by Tenório). For Pinho and Santos (2015), the debate provoked by Tenório, associating social management and the public sphere, indicates that in the current Brazilian economic and social context, the economy is a requisite of democracy, in any of the two categories and, therefore, the classic formulation that democracy refers to freedom and equality, continues to apply.

Oliveira, Cançado and Pereira (2010) and Cançado, Tavares and Dallabrida (2013) quote the work Mudança estrutural da esfera pública: investigações quanto a uma categoria da sociedade burguesa (HABERMAS, 2003) to address the existence of a multitude of views on the meanings of Habermas' public and public sphere, clarifying that only with the appearance of the modern State do the categories of public and private have an effective legal procedural application, with this moment being the milestone from which the concept of public sphere starts to represent the possibility of systematizing society in one of his central categories. 
Only Tenório (1998) cites the works Teoria e práxis: estudos de filosofia social (HABERMAS, 2011) and A necessidade de revisão da esquerda (HABERMAS, 1991). In relation to the first work, Tenório (1998) addresses Habermas' proposal of preparing a theory of society that, unlike traditional, positivist theory, makes a social praxis possible, focused on reflexive knowledge and a policy questioning the existing socio-political-economic structures, proposing an approach that frees man of dogmatism and contributes to his emancipation. With regards to the second work, Tenório (1998) mentions the argument as a procedure to solve problems, with it being a type of speech, in which the participants of a specific action focus on claims of validity and address implementing or refusing them through arguments.

With regards to the analysis of the epistemological basis, a list of articles with Burrel and Morgan's (1979) paradigms: functionalism; interpretative; radical humanism and structuralism was investigated. The interpretivist approach is predominant, present in 16 articles. The remaining two can be classified in the radical humanist and radical structuralist paradigms. Although Cançado (2011) characterizes and approaches the field of knowledge of social management of the radical humanism paradigm, the studies analyzed steer towards the interpretivist field. The interpretivist bias is evident when the articles take trajectories of empirically seeing the social world as created by those involved. They approach subjects that permeate social management and deliberative citizenship related to consensus, integration, solidarity, cooperation and participation but without making advances on issues, such as the status quo and emancipation, which are the bases of radical humanism and theoretical-critical perspective of the Frankfurt School. On the other hand, the fact that the studies distance themselves from the instrumental, pragmatic and hegemonic functionalist nature in the field of administrative science, as reported by Guerreiro Ramos (1981), is clear.

All the articles have a qualitative, methodological nature. This finding is in line with the epistemological basis and the field of studies of social management, since the interpretivist paradigm takes intersubjective analyses, an important relation in Jürgen Habermas' communicative action and the field of social management. The predominance of the qualitative methodological approach demonstrates the authors' interest in investigating the phenomena studied in greater depth and focusing on experiences and subjects. This approach is in line with social management, orientated by communicative rationality and deliberative citizenship, where decisions are made through dialogue and knowledge. In other words, discursively, and the subject and their experiences are important sources in the knowledge construction process. The qualitative approach is equally related to the ideographic, methodological nature of social management, when it allows the subject-researcher to reveal their own nature during the research. For this reason, it is pertinent to accept the understanding that quantitative methodological procedure, which is guided by the use of natural science methods (constructions of hypothesis tests and quantitative data analysis), does not enable the nuances in social management to be seen (CANÇADO, 2011).

Of the 18 articles, 7 have an exclusively theoretical approach. The presence of theoretical research in science should be considered a positive factor, since literature is constantly reviewed, interlaced and, consequently improved through it, to the point of generating new concepts, constructs and even new theories. This is the reality of the field of social management, which still triggers constant and enriching debates and discussions that seek its establishment, as current studies demonstrate. The "case study" (6) and "document research" (6) are predominant, as indicated in Table 1. The case study is present in theoretical-empirical studies and the majority have the aim of analyzing councils and territorial collegiates, understood as spaces that allow the participation of society in the preparation, implementation and control of public policies. On considering the plurality of types of communication and discussion, in which the forms of deliberation guarantee participation with equal conditions in the formulation and implementation of public policies, these spaces allow the practice of Habermas' deliberative citizenship (as understood by the authors).

The data collection technique most used was the interview (9), which shows that research into social management, interfaced with deliberative citizenship, has been directed by the construction of knowledge, and based on experiences and perceptions of different subjects and social groups with activities in the public sphere. There are only two analysis techniques: "content analysis" and "intersubjective analysis". These procedures are in line with the main types of data collection. Although the intersubjective analysis was only applied in one study, it mediates the majority of the theoretical-empirical studies found. 
Table 1

Methodological Profile

\begin{tabular}{|c|c|c|}
\hline \multirow{2}{*}{ Characteristic observed } & \multicolumn{2}{|c|}{ Description } \\
\hline & Elements & Frequency \\
\hline \multirow{4}{*}{ Approach } & Qualitative & 18 \\
\hline & Quantitative & 0 \\
\hline & Mixed (quali-quanti) & 0 \\
\hline & Total & 18 \\
\hline \multirow{8}{*}{ Data collection method } & Case study & 6 \\
\hline & Document research & 6 \\
\hline & Field survey & 2 \\
\hline & Hermeneutic & 2 \\
\hline & Bibliographical research & 2 \\
\hline & Oral history & 2 \\
\hline & Participant methodologies & 1 \\
\hline & Total & $20 *$ \\
\hline \multirow{7}{*}{ Data collection techniques } & Interviews & 9 \\
\hline & Questionnaires & 4 \\
\hline & Documentation & 4 \\
\hline & Observation & 3 \\
\hline & Sensemaking & 1 \\
\hline & Focal group & 1 \\
\hline & Total & $22 *$ \\
\hline \multirow{3}{*}{ Data analysis techniques } & Content analysis & 7 \\
\hline & Intersubjective analysis & 1 \\
\hline & Total & 8 \\
\hline
\end{tabular}

Source: Elaborated by the authors.

* The occurrence of a higher number than the number of articles analyzed is due to having cases of simultaneous use of two forms/typologies.

A reading of the deliberative citizenship construct contributes towards the theoretical and empirical debate in the works analyzed in the field of social management. The theoretical texts indicate that the construct is a relevant base to construct the domain of this field and empirical research demonstrates this applicability, indicating that Habermas' process of deliberative citizenship may represent the strategy required for its institutionalization. Research in rural territories reveals that social management and deliberative citizenship may form sustainable territorial development strategies, through participation by different actors, in the preparation and introduction of public policies (IIZUKA, GONÇALVES-DIAS and AGUERRE, 2012); in promoting communication that strives for the participation of society (ALLEBRANDT, BENSO and OLIVEIRA, 2015); and for the understanding that the deliberative citizenship process is permeated by various facts, dialogues and unexpected, non-linear events (IIZUKA, GONÇALVES-DIAS and AGUERRE, 2011).

Research in development councils also shows how they produce changes in the public perspective of individuals, in the culture of civil society, the profile of political society and the modus operandi of the bureaucratic apparatus and governments (ALLEBRANDT, SIEDENBERG, SAUSEN et al., 2011). In addition, they also conduct decentralized decision-making processes, being spaces that achieve engaging management, in an attempt to increasingly mobilize society (CHASSOT and ALLEBRANDT, 2016). Thus, it is clear that dialogue and the participation of actors in the preparation and introduction of public policies are essential when the promotion of transformations in social phenomena is sought. 
The theoretical articles assume that social management is a domain under construction and, for this reason, continue to provide ideas and concerns, in order to establish the field. The authors consider social management a theoretical and practical alternative to hegemonic organizational thinking. They indicate that the topic is strongly related to the topics of the public bureaucratic apparatus and the decision-making process that takes place in the public sphere, when actors from civil society and the State interact, with the common goal of promoting expanded public administration. These spaces only have meaning - from the perspective of social management and deliberative citizenship - if the interested parties take part in the decision-making process. Brazilian society has (re)created spaces in which public action becomes possible through dialogue, participation and deliberative citizenship and, therefore, by indicating that the public sphere forms a base to understand and establish phenomena within the area of administrative science, the authors define a locus for social management in scientific knowledge.

\section{FINAL CONSIDERATIONS}

This review systematizes how Habermas' concept of deliberative citizenship is applied in social management studies in Brazil. The results show that of the 18 articles collected, 9 are published in journals with a Qualis A2 classification, whereas the other 9 are in journals with Qualis B1 to B4 classification. The Cadernos EBAPE.BR journal has a higher volume of publications with both keywords deliberative citizenship and social management, accounting for five records. It is the first publication with the keywords "1998 data" (Fernando Guilherme Tenório, Revista de Administração Pública), whereas 2011 is the year with the highest number of publications (6). The most recent publications date from 2015 (3).

With regards to the methodological approach, qualitative analyses predominate and 7 articles are characterized as theoretical essays. The other 11 are empirical studies, mainly undertaken at territorial collegiates and public policy councils. The author, Fernando Guilherme Tenório, is quoted in all the articles analyzed. In addition to deliberative citizenship, Habermas' other concepts, such as communicative action, communicative rationality, the public sphere, participation and argumentation, serve as a basis to democratize approaches of social relations and, particularly, to orientate ideas on human emancipation. With regards to the epistemological basis, the interpretivist approach is predominant.

The research findings demonstrate that the way social management authors use the concept of deliberative citizenship in Brazil converges with how the concept is used in Habermas' work; in other words, as being type of citizenship based on a specific political style and the practice of deliberative democracy, mediated by other concepts, such as communicative action and communicative rationality. It is concluded that Tenório's (1998) original reading was maintained for 20 years and, therefore, the concept of deliberative citizenship is in line with social management and contributes towards theoretical debate and empirical studies in the field of civil society organizations, particularly in collegiates. On the other hand, studies involving social management and deliberative citizenship, by means of application with state public and private sector organizations - as Tenório (1998) originally suggested, are in short supply in Brazil. In turn, the results of the theoretical-empirical articles provide reflections on the challenges and opportunities of social management, indicating that Habermas' process of deliberative citizenship may represent the strategy required for the establishment of the field. However, the results of the theoretical articles indicate that social management is under construction and, therefore, provide baselines for its formulation.

As a limitation of this review exercise, it should be highlighted that only Habermas' concept of deliberative citizenship was used as a criterion to select the articles and, therefore, we suggest that future studies analyze this author's other concepts, associated to the field of social management. Another possibility is the use of Habermas' concepts in theses and dissertations on administration in Brazil, which may reveal how Habermas is considered in other areas of administrative science, besides social management. Seen in these terms, it is important to emphasize that the understanding that social management may take place not only in the third sector, civil society organizations, but also in decision-making environments discussed in state public and private organizations, is clear in Tenório's (1998) original text. From the information processed here, this bias has not had an impact on Brazilian researchers and this fact deserves attention and further investigation. 


\section{REFERENCES}

ALLEBRANDT, S. L. et al. Gestão social e cidadania deliberativa: uma análise da experiência dos Coredes no Rio Grande do Sul, 1990-2010. Cadernos EBAPE.BR, Rio de Janeiro, v. 9, n. 3, p. 914-945, 2011.

ALLEBRANDT, S. L.; BENSO, A.; OLIVEIRA, V. G. Interfaces entre a comunicação e a gestão social no contexto do desenvolvimento territorial: um estudo do território da cidadania noroeste colonial do Rio Grande do Sul. Revista de Ciências da Administração, v. 17, n. 1, p. 120-133, 2015.

BURRELL, G.; MORGAN, G. Sociological paradigms and organizational analysis. London: Heinemann, 1979.

CANÇADO, A. C. Fundamentos teóricos da gestão social. 2011. 146 p. Thesis (Doctorate in Administration) - Federal University of Lavras, Lavras, 2011.

CANÇADO, A. C.; TAVARES, B.; DALLABRIDA, V. R. Gestão social e governança territorial: interseções e especificidades teórico-práticas. Revista Brasileira de Gestão e Desenvolvimento Regional, v. 9, n. 3, p. 313-353, 2013.

CANÇADO, A. C.; TENÓRIO, F. G.; PEREIRA, J. R. Gestão social: reflexões teóricas e conceituais. Cadernos EBAPE.BR, Rio de Janreiro, v. 9, n. 3, p. 681-703, 2011.

CARRION, R. S. M. Gestão social: especificidades e práticas em discussão. In: SILVA, J. G. et al. (Org.). Tecnologias de gestão: por uma abordagem multidisciplinar. Vitória: UFES, 2007. p. 108-124.

CHASSOT, J. P.; ALLEBRANDT, S. L. Processos de discussão em espaços públicos: a gestão social dos conselhos municipais de desenvolvimento do noroeste colonial do estado do Rio Grande do Sul. PRACS: Revista Eletrônica de Humanidades do Curso de Ciências Sociais da Unifap, v. 8, n. 2, p. 247-265, 2016.

FISCHER T. Poderes locais, desenvolvimento e gestão: uma introdução a uma agenda. In: FISCHER T. (Org). Gestão do desenvolvimento e poderes locais: marcos teóricos e avaliação. Salvador: Casa da Qualidade, 2002. p. 12-32.

FRANÇA FILHO, G. C. Gestão social: um conceito em construção. In: COLÓQUIO INTERNACIONAL SOBRE PODER LOCAL, 9., 2003, Salvador. Anais... Salvador: CIAGS/UFBA, 2003.

FRANÇA FILHO, G. C. Definindo gestão social. In: SILVA JÚNIOR, J. T. et al. (Org.). Gestão social: práticas em debate, teorias em construção. Fortaleza: UFC, 2008. p. 27-37.

FREITAG, B. A teoria crítica: ontem e hoje. 5. ed. São Paulo: Brasiliense, 1994.

GALVÃO, T. F.; PANSANI, T. S. A.; HARRAD, D. Principais itens para relatar revisões sistemáticas e meta-análises: a recomendação Prisma. Revista Epidemiologia e Serviços de Saúde, v. 24, n. 2, p. 335-342, 2015.

GARCIA, A. S. Esferas públicas como uma categoria fundante da gestão social. 2016. 273 p. Dissertation (Master's in Administration) - Federal University of Lavras, Lavras, 2016.

GUERREIRO RAMOS, A. A nova ciência das organizações: uma reconceituação da riqueza das nações. Rio de Janeiro: Fundação Getulio Vargas, 1981.
HABERMAS, J. Teoria do agir comunicativo. Racionalidade da ação e racionalização social. São Paulo: WMF Martins Fontes, 2011a, v. 1.

HABERMAS, J. Teoria do agir comunicativo. Sobre a crítica da razão funcionalista. São Paulo: WMF Martins Fontes, 2011b, v. 2.

HABERMAS, J. Teoria e práxis: estudos de filosofía social. São Paulo: Unesp, 2011.

HABERMAS, J. La necesidad de revisión de la izquierda. Madrid: Tecnos, 1991.

HABERMAS, J. Três modelos normativos de democracia. Lua Nova, n. 36, p. 39-54, 1995.

HABERMAS, J. Direito e democracia: entre facticidade e validade. Rio de Janeiro: Tempo Brasileiro, 1997.

HABERMAS, J. Mudança estrutural da esfera pública: investigações quanto a uma categoria da sociedade burguesa. Rio de Janeiro: Tempo Brasileiro, 2003.

IIZUKA, E. S.; GONÇALVES-DIAS, S. L. F.; AGUERRE, P. Gestão social e cidadania deliberativa: a experiência de Ilha Comprida - São Paulo. Cadernos EBAPE.BR, Rio de Janeiro, v. 9, n. 3, p. 748-779, 2011.

IIZUKA, E. S.; GONÇALVES-DIAS, S. L. F.; AGUERRE, P. Reflexões sobre o desenvolvimento territorial sustentável, gestão social e cidadania deliberativa: o caso da bacia do rio Almada (BA). Revista de Administração Pública, Rio de Janeiro, v. 46, n. 6, p. 1599-1623, 2012.

NUBE DE PALABRAS. Available at: <https://goo.gl/M1vKLP>. Accessed on: July 19, 2017.

OLIVEIRA, V. A. R.; CANÇADO, A. C.; PEREIRA, J. R. Gestão social e esfera pública: aproximações teórico-conceituais. Cadernos EBAPE. BR, Rio de Janeiro, v. 8, n. 4, p. 613-526, 2010.

OliveirA, C.; PERAFÁn, M. E.; CONTERATO, M. A. Percepção de atores sociais sobre gestão estratégica e gestão social no âmbito da política de desenvolvimento territorial no Brasil. Desenvolvimento Regional em Debate, v. 3, n. 2, p. 154-175, 2013.

PERES JÚNIOR, M. R.; PEREIRA, J. R.; OLIVEIRA, L. C. Gestão social sob a lente estruturacionista. Revista de Administração Mackenzie, v. 14, n. 6, p. 18-49, 2013.

PERSSON, E. Burocracia, ideologia e gestão social: uma abordagem crítica à luz da categoria habermasiana da esfera pública. 2016. 353 p. Dissertation (Master's in Administration) - Federal University of Santa Catarina, Florianópolis, 2016.

PINHO, J. A. G.; SANTOS, M. E. P. Aporias em torno do conceito de gestão social: dilemas teóricos e políticos. Revista de Gestão USP, v. 22, n. 2, p. 155-172, 2015.

SILVA, T. S.; LIMA, A. A. T. F. C.; GOMIDE, S. C. Inovação na administração pública: um meta estudo dos anais do Enanpad. Capital Científico, v. 15, n. 1, p. 141-159, 2017.

SILVEIRA, D. T.; CÓRDOVA, F. P. A pesquisa científica. In: GERHARDT, T. E.; SILVEIRA, D. T. (Org.). Métodos de pesquisa. Porto Alegre: UFRGS, 2009. p. 31-42. 
Deliberative citizenship and social management: a systematic literature review in Brazil
Rafael Junior dos Santos Figueiredo Salgado Luana Ferreira dos Santos | Tamiris Cristhina Resende Washington José de Souza
SOUZA, W. J.; OLIVEIRA, M. D. Fundamentos da gestão social na revolução industrial: leitura crítica aos ideais de Robert Owen. Organizações \& Sociedade, v. 13, n. 39, p. 59-76, 2006.

TENÓRIO, F. G. Gestão social: uma perspectiva conceitual. Revista de Administração Pública, Rio de Janeiro, v. 32, n. 5, p. 7-23, 1998.

TENÓRIO, F. G. (Re)visitando o conceito de gestão social. Desenvolvimento em Questão, v. 3, n. 5, p. 101-124, 2005.

TENÓRIO, F. G. A trajetória do Programa de Estudos em Gestão Social (Pegs). Revista de Administração Pública, Rio de janeiro, v. 40, n.6, p. 1145-1162, 2006.

TENÓRIO, F. G. Um espectro ronda o terceiro setor, o espectro do mercado. 3. ed. Ijuí, RS: Unijuí, 2008a.
TENÓRIO, F. G. Tem razão a administração? 3. ed. ljuí, RS: Unijuí, 2008b.

TENÓRIO, F. G. A trajetória do programa de estudos em gestão social (PEGS). In: SILVA JUNIOR, J. T. et al. Gestão social: práticas em debate, teorias em construção. Fortaleza: Imprensa Universitária, 2008c. p. 142-159.

TENÓRIO, F. G. Gestão social: uma réplica. In: RIGO, A. S. et al. Gestão social e políticas públicas de desenvolvimento: ações, articulações e agenda. Recife: Univasf, 2010. p. 57-62.

VILLELA, L. E.; PINTO, M. C. S. Governança e gestão social em redes empresariais: análise de três arranjos produtivos locais (APLs) de confecções no Estado do Rio de Janeiro. Revista de Administração Pública, Rio de Janeiro, v. 43, n. 5, p. 1067-1089, 2009.

Rafael Junior dos Santos Figueiredo Salgado

ORCID: https://orcid.org/0000-0003-2388-0605

PhD student in Administration at the Federal University of Rio Grande do Norte (UFRN), Natal - RN, Brazil. E-mail: rafa.salgad@gmail.com

Luana Ferreira dos Santos

ORCID: https://orcid.org/0000-0002-3347-7740

PhD student in Administration at the Federal University of Rio Grande do Norte (UFRN), Natal - RN, Brazil. E-mail: luana.f.s.adm@gmail.com

Tamiris Cristhina Resende

ORCID: https://orcid.org/0000-0002-7354-2658

PhD student in Administration at the Federal University of Rio Grande do Norte (UFRN), Natal - RN, Brazil. E-mail: tamiriscristhina@gmail.com

Washington José de Souza

ORCID: https://orcid.org/0000-0001-6295-2806

PhD in Education from the Federal University of Ceará (UFC); Professor in the Department of Public Administration and Social Management at the Federal University of Rio Grande do Norte (UFRN), Natal - RN, Brazil. E-mail: wsufrn@gmail.com 